\title{
METAFÍSICA LEIBNIZIANA DA COMUNICAÇÃO O PARADIGMA MONADOLÓGICO
}

\author{
Adelino Cardoso \\ CHC, Faculdade de Ciências Sociais e Humanas, \\ Universidade Nova de Lisboa
}

\begin{abstract}
"Ora, esta ligação ou este acomodamento de todas as coisas criadas a cada uma e de cada uma a todas as outras, leva a que cada substância simples tenha relações que exprimem todas as outras e que, por conseguinte, seja um espelho vivo perpétuo do universo." 1
\end{abstract}

Introdução. O traço mais característico do sistema leibniziano reside porventura no significado que aí é reconhecido à comunicação. Trata-se de uma noção nuclear, que assume diferentes modos, graus e, inclusive, sentidos. Como procurarei mostrar, esses vários sentidos - metafísico, moral, jurídico, histórico-antropológico - fazem sistema e, mais, encontram o seu máximo de intensidade e vigor na fase monadológica, aquela que justamente é a expressão culminante do leibnizianismo.

\section{Siglas e Abreviaturas}

A Leibniz, Gottfried Wilhelm, Sämtliche Schriften und Briefe. Herausgegeben von der Deutschen Akademie der Wissenschaften zu Berlin, Darmstadt, 1923 segs, Leipzig, 1938 segs, Berlin, 1950 segs. (A referência será feita em três números: série, tomo, página).

C Couturat, Louis (Ed.), Opuscules et Fragments inédits de Leibniz extraits des manuscrits de la Bibliothèque royale de Hanovre, Paris, 1903. Reimp. Hildesheim, 1961.

GP Leibniz, Gottfried Wilhelm, Die philosophischen Schriften. Ed. C. I. Gerhardt, 7 vols. Berlin, 1857-1890. Reimp. Hildesheim, 1965.

Grua Leibniz, Gottfried Wilhelm, Textes inédits d'après les manuscrits de la Bibliothèque provinciale de Hanovre. Ed. G. Grua, 2 vols. Paris, 1948.

${ }^{1}$ Monadologia, art. 56.

Philosophica, 37, Lisboa, 2011, pp. 7-23 
Por conseguinte, entendo demarcar-me da leitura preguiçosa e superficial que a mais comum vulgata leibniziana faz da célebre fórmula de que “a mónada não tem portas nem janelas" por onde algo de exterior possa introduzir-se nela, diminuindo a sua autonomia e dinamismo intrínsecos ${ }^{2}$. Por maioria de razão, demarco-me da desleitura operada por Alain Renaut a respeito do significado histórico-sistemático da obra leibniziana e da dinâmica que o articula. Segundo este autor, Leibniz representa o desembocar do cogito racionalista num individualismo sem sujeito ${ }^{3}$, o fechamento do eu em si mesmo, sem qualquer relação com o outro e com o mundo: "uma subjectividade sem intersubjectividade, uma identidade a si que se põe sem nenhuma relação com a alteridade de um mundo nem de um outro"4. Solipsismo e atomismo encontrariam na monadologia o seu quadro de eleição, acrescendo que o indivíduo assim erigido em absoluto é ele próprio vazio, uma contínua reiteração de uma mesma identidade fundamental do universo: "As diferenças entre as mónadas são assim meras diferenciações a partir de uma identidade fundamental, que corresponde à identidade a si do universo" 5 .

A questão muito certeiramente colocada por Renaut - "Como pensar relações de ordem, como conceber relações entre realidades intrinsecamente separadas?” - é uma boa questão, mas, longe de ser o "paradoxo" inscrito no estilo monadológico inaugurado por Leibniz (ibid.), é ela que trabalha e impulsiona o exercício leibniziano do pensar, na procura de um topos mediador, a igual distância do holismo e do individualismo ${ }^{7}$. Com efeito, o programa monadológico é justamente o de estabelecer a coerência de um universo irredutivelmente pluralista, não totalizável.

\footnotetext{
${ }^{2}$ A interpretação proposta por Alain Badiou é típica sob este aspecto: "Mas pode igualmente dizer-se: já que os "pontos metafísicos» apenas são discerníveis pelas suas qualidades internas, devemos pensá-los como interioridades puras - é o aforismo: «As mónadas não têm janelas» - e por conseguinte como sujeitos. No entanto este sujeito, que nenhum descentramento da lei fende, e cujo desejo não é despertado por nenhum objecto, é na verdade um puro sujeito lógico. O que parece advir-lhe é tão-só o desenrolar dos seus predicados qualitativos. É uma tautologia prática, uma reiteração da sua diferença." (Badiou, A., L'être et l'événement, Paris, Seuil, 1988, p. 357).

3 "Fantástica dissolução paralela da subjectividade e da intersubjectividade, a monadologia é neste sentido o acto de nascimento filosófico do indivíduo e do individualismo" (Renaut, A., L'Ère de l'individu, Paris, Gallimard, 1989, p. 140).

${ }^{4}$ Op. cit., p. 131.

${ }^{5}$ Op. cit., p. 148.

${ }^{6}$ Op. cit., p. 154.

${ }^{7}$ Procurar um terreno mediador no qual seja superado o abismo entre holismo e individualismo é um procedimento bem distinto de visar "uma conciliação entre princípios irredutivelmente heterogéneos” (Renaut, A., Op. cit., p. 100).
} 
1. Indivíduo e comunidade. A inscrição da comunicação na espontaneidade do ser é uma das molas da reformulação do leibnizianismo até alcançar o seu máximo de coerência na versão monadológica. Em termos esquemáticos, proponho-me focar a lógica imanente ao evolver da metafísica leibniziana em que a reiterada afirmação do indivíduo caminha a par com a resistência ao individualismo.

Como bem atesta a sua primeira obra - Disputatio de principio individui (1663) -, a formação intelectual de Leibniz está fortemente impregnada da metafísica escolástica, mormente na versão de F. Suárez, que assume vigorosamente o primado do indivíduo: o próprio conceito genérico de ser não passa de um modo inadequado de a inteligência humana visar o ser individual, pelo que o seu estatuto é o de um conceito meramente objectivo ${ }^{8}$. Na sua Disputatio, Leibniz retoma a tese central das Disputationes (1597) suarezianas: a entidade é o dado último9 ${ }^{9}$, o princípio de constituição e distinção do ente, num dinamismo que se identifica por inteiro com o processo de individuação. Na formulação suareziano-leibniziana, a individuação opera-se, não pela forma ou pela matéria tomadas isoladamente, mas pela entitas tota ${ }^{10}$, o que significa que a individuação consiste basicamente num trabalho de integração pelo qual uma entidade se constitui como unidade que liga numa totalidade a pluralidade dos seus acidentes.

Os contornos da metafísica inscrita na Disputatio tocam num individualismo atomístico em que não se vislumbra nenhum vínculo efectivo entre os seres individuais, sendo manifestamente insuficiente afirmar a sua comum pertença ao ser, que não constitui uma verdadeira comunidade. Por sua vez, a simples inteligibilidade de um mundo constituido por entes individuais levanta a questão da sua ligação interna. Como estabelecer uma ordem inter-individual se os indivíduos não comunicam entre si?

Leibniz tem consciência da dificuldade que existe em conciliar o primado do indivíduo, o seu carácter originário, com a exigência do vínculo comunitário. Daí a formulação muito explícita, se bem que requerendo um mais vasto enquadramento sistemático, contida num escrito de

${ }^{8}$ A este respeito, veja-se, Cardoso, A., “A transformação suareziana da metafísica”, in Calafate, Pedro, História do Pensamento Filosófico Português, II tomo, Lisboa, Caminho, 2001, pp. 559-575.

9 “(...) cada coisa é pela sua entidade” (res quaelibet per suam Entitatem est) (Leibniz, Disputatio, § 5).

${ }^{10}$ A entitas tota é a inteligibilidade fundamental do ser, a sua medida própria. Ser é ser-indivíduo: “(...) a entidade inteira é, em termos universais, o princípio universal do ente” (tota entitas est principium Entis universale in universali). (Leibniz, Disputatio, § 7). 
1663/66: "Nenhum ser (ens) na natureza inteira é solitário, mas todo o ente (ens) é simbiótico, isto é, pertence a uma sociedade."11 O intento leibniziano de fazer de inserir o indivíduo num habitat comum é claro, mas é ainda razoavelmente obscuro o modo dessa inserção, que é relegado para o domínio do inefável, como algo que supera os limites da nossa compreensão: "Daí o inefável comércio e a infinita união e comunhão de todas as coisas" (ibidem). E todavia, avança-se neste mesmo escrito algo de equiparável a um princípio comunitário no processo de autoconstituição do ente. $A$ génese do individuo pressupõe um universo comum no seio do qual ele se distingue e diferencia: "Toda a diferença positiva se funda na conveniência ou unidade e, portanto, todas as coisas que diferem entre si positivamente também convêm necessariamente entre si."12 Por conseguinte, a entidade discreta, que se constitui na referência exclusiva a si, não é simplesmente pensável.

Um opúsculo de 1677, intitulado De iis quae per se concipiuntur, recoloca a uma nova luz o princípio leibniziano da comunidade, afastando a tendência para o substancializar. O ponto de focagem deste escrito é o ser na sua forma infinitiva (esse), não substantiva (ens). O que está em jogo é o esse enquanto tal, não enquanto ele está vinculado a tal ou tal entidade: "É óbvio que o próprio ser (esse) se concebe por si. Se, com efeito, avançamos que se concebe por outras coisas, como a e b, é óbvio que a respeito destas também se pode conceber o próprio ser; o que é absurdo. Logo, a existência é indecomponível (incomposita) ou seja irresolúvel"13. Muito sucintamente, seria absurdo pretender focar o ser de uma entidade porquanto não há distinção real entre uma coisa e a outra, pode focar-se, sim, a especificidade do ser em acto, isto é, o modo pelo qual ele se exerce.

Sem que a palavra seja expressamente utilizada, o que se anuncia aqui é o princípio de compossibilidade enquanto requisito fundamental de adveniência do real: a diferença pura, isto é, a simples entidade abstraída de qualquer relação, carece em absoluto de realidade. Como é lapidarmente expresso: "Digo que a diferença pura não contém realidade porque a realidade é algo de comum, que não deve estar contido na diferença pura"14. No limite, a entidade em si, distinta de todas as outras (isto é, a diferença pura), é uma noção vazia e abstracta, meramente nominal: “(...) por conseguinte, não devemos postular uma certa diferença última” (ibid.). O próprio e o comum jogam indissociavelmente um com o outro, o que se ajusta ao modo pelo qual se exerce o pensar, que não é nunca

\footnotetext{
11 Notae ad J. Henricum Bisterfeldim, A VI, I, p. 153.

12 Op. cit., p. 155.

13 De iis quae per se concipiuntur, A VI, IV, A, p. 25.

14 Op. cit., p. 26.
} 
vazio, simples acto de um eu que se coloca em face de um pensável. O pensar situa-se num ponto de intersecção, como elo de ligação entre diferenciados: "não pensamos nada de absolutamente simples" (ibid.).

O Discurso de Metafisica (1686) fornece a primeira elaboração sistemática do leibnizianismo, cuja significação é em larga medida elucidada na intensa correspondência com Arnauld, subsequente à recepção pelo ilustre Teólogo do sumário dos 37 artigos da obra, que se manteve longamente inédita. A escolha de Arnauld como interlocutor privilegiado do DM não tem nada de acidental: Leibniz aprecia o vigor e a solidez da argumentação arnaldiana, mas receia que a intransigência do Patriarca de Port-Royal aprofunde as divisões filosófico-teológicas que afectam a Europa no final do século XVII. O DM responde, de algum modo, à exigência de estabelecer um núcleo comum de noções, superando o espírito de seita que tende a prevalecer entre os diferentes "partidos". Não se trata de anular as diferenças e inibir a sua expressão, mas de procurar a sua inteligibilidade recíproca.

A filosofia é um exercício de inteligibilidade, a procura de uma ordem imanente aos fenómenos contingentes que ocorrem na natureza e na existência humana. Contingência joga com uma inteligibilidade físico-moral, a igual distância do necessitarismo estrito e do acaso fortuito.

O indivíduo é razão e fundamento de todos os seus fenómenos, a lei imanente da série de todos os estados que o afectam. É o que significa o termo completo, pelo qual se define o carácter próprio da substância individual: "Sendo assim, podemos dizer que a natureza de uma substância individual ou de um ser completo é ter uma noção tão acabada que seja suficiente para compreender e deduzir a partir dela todos os predicados do sujeito a que tal noção é atribuída" 15 . Noção completa designa também e principalmente o indivíduo enquanto expressão, à sua escala, do mundo no qual se desenrola a sua existência ${ }^{16}$ : "De igual modo, quando se considera bem a conexão das coisas, pode dizer-se que existem desde sempre na alma de Alexandre vestígios de tudo quanto lhe aconteceu e as marcas de tudo o que se passa no universo, se bem que só a Deus caiba reconhecê-los a todos.”17 Assim, completo refere-se ao ser individual enquanto ele contém, à sua escala, a estrutura de todo um mundo. Enquanto completa, toda a substância é um mundo, contendo tanta ordem quanta a do universo: "Ora, cada

\footnotetext{
15 Discurso de Metafísica, art. 8.

${ }^{16}$ Nos termos concisos de Michel Fichant: "Melhor ainda: a determinação completa da individualidade assenta na consideração da copertença a um mundo que se especifica entre todos os mundos possíveis” (Fichant, M., Science et métaphysique dans Descartes et Leibniz, Paris, PUF, 1998, p. 132).

17 Ibidem.
} 
substância individual deste universo exprime na sua noção o universo no qual ela entra. (...) porque a natureza de uma substância individual consiste em ter uma tal noção completa da qual se pode deduzir tudo o que lhe pode ser atribuído e mesmo o universo por causa da conexão das coisas”18. Por conseguinte, o indivíduo não é um simples fragmento do universo, é "parte total” (GP II, p. 263), no sentido em que ele é todo o mundo sob uma forma singular. A expressão é o princípio regulador da génese e funcionamento do mundo actual. Ela é comum a todas as formas e traduz-se na correspondência e ordenação mútua de todos os seres e fenómenos: "Uma coisa exprime uma outra (na minha linguagem) quando há uma relação constante e regrada entre o que se pode dizer de uma e da outra. É assim que uma projecção de perspectiva exprime o seu geometral. A expressão é comum a todas as formas, e é um género de que a percepção natural, o sentimento animal e o conhecimento intelectual são espécies.”19

Num universo regulado pela expressão, não há uma figura própria do mundo, que é inteiramente dessubstancializado. Por seu lado, o indivíduo afirma-se como "perfil do universal" 20 , um ponto de vista num dinamismo entre-expressivo: "Pois, virando Deus, por assim dizer, de todos os lados e de todas as maneiras, o sistema geral dos fenómenos que acha bom produzir para manifestar a sua glória e olhando todas as faces do mundo de todas as maneiras possíveis, já que não existe nenhuma relação que escape à sua omnisciência, o resultado de cada vista do universo, enquanto olhado de um certo local, é uma substância que exprime o universo em conformidade com essa vista, se Deus considera bom tornar efectivo o seu pensamento e produzir tal substância." 21 A substância individual realiza o mundo enquanto "sistema geral dos fenómenos" através da sua potência expressiva. Há graus de expressão, que vão desde a simples matéria animada até aos espíritos superiores. Exprimir é realizar uma nova possibilidade do mundo, unificar a multiplicidade dos seus fenómenos sob a unidade de um ponto de vista, dar uma fisionomia original ao comum.

O DM acompanha o esforço de invenção de uma nova física, distinta da mecânica, que trata o movimento como um fenómeno geométrico, elucidável pela extensão. Com efeito, a natureza material não é simples extensão, os corpos físicos estão investidos de uma força que lhes confere uma acção espontânea: "o movimento em si, desligado da força, é algo de meramente relativo", "mas a força é qualquer coisa de real e absoluto" 22 .

18 Carta a Arnauld, de 21-31. 05. 1686, GP II, p. 41.

19 Carta a Arnauld, de 9. 10. 1687, GP II, p. 112.

20 Serres, M., Le système de Leibniz et ses modèles mathématiques, Paris, 1968, p. 555.

${ }^{21}$ Discurso de Metafisica, § XIV.

22 Carta a Arnauld, 14. 01. 1688, GP II, p. 133. 
A fundação leibniziana da dinâmica visa superar a homogeneidade e indiferenciação do espaço geométrico, reconhecendo a diversidade implicada na natureza animada ${ }^{23}$.

Enquanto sujeito da força, o corpo físico ganha substancialidade e algum grau de unidade: não um simples agregado de partes extrinsecamente justapostas umas às outras, mas um composto no qual as partes se ajustam naturalmente, por si. Ora o composto não pode existir sem o simples. O composto exige um princípio de composição, requer o simples como seu fundamento. Mas também o simples só tem cabimento na sua relação ao composto.

O significado da monadologia reside precisamente na correlação entre simples e composto: "A mónada de que falamos aqui não é outra coisa senão uma substância simples, que entra nos compostos"24. Ao contrário do que pretende a vulgarizada exegese leibniziana, mónada e substância composta exigem-se mutuamente. A coerência entre ambas é a articulação fundamental do universo monadológico, dando-lhe o carácter de uma filosofia da vida enquanto exercício singular de comunicação.

A relação entre o simples e o composto não é de exterioridade mútua, é de copertença originária, uma relação de simbolização no sentido em que Marie Cariou interpreta a fórmula do art. 61 da Monadologia: "E nisso os compostos simbolizam com os simples" - o de um misto primordial ${ }^{25}$. Considerada em si mesma, sem referência ao composto, a mónada carece de realidade e função: ela é no e para o composto. Como é dito à princesa Sofia: "Vossa Alteza pergunta-me o que é uma substância simples. Respondo que a sua natureza consiste em ter percepção e, por conseguinte, em representar as coisas compostas" 26 .

O vinculum substancial é o mediador pelo qual se estabelece a liga-

23 “A suposição da extensão absolutamente nua destrói toda esta maravilhosa variedade, a simples massa (se fosse possível concebê-la) está tão abaixo de uma substância que é perceptiva e representação de todo o universo segundo o seu ponto de vista e segundo as impressões (ou melhor, as relações) que o seu corpo recebe mediata ou imediatamente de todos os outros, como um cadáver está abaixo de um animal, ou melhor, como uma máquina está abaixo de um homem.” (Carta a Arnauld, 30. 04. 1687, GP II, p. 98).

24 Monadologia, art. 1.

25 “[Simbolizar] É, em primeiro lugar, o termo mais próprio para apagar a ideia de uma separação prévia de dois termos a unir sem todavia ser o equivalente de um confusionismo indeciso. «Simbolizar» é o verbo simultaneamente poético e místico que traduz a inerência: o mesmo no outro, o múltiplo no uno. Este vocabulário, aliás alquímico, permite designar uma mistura primitiva indissociável cujos componentes são no entanto específicos.” (Cariou, M., L'atomisme. Gassendi, Leibniz, Bergson et Lucrèce, Paris, Aubier, 1978, p. 123).

${ }^{26}$ Carta à princesa Sofia, de 6. 02. 1706, GP VII, p. 566. 
ção e a continuidade entre o simples e o composto ${ }^{27}$. O seu estatuto não é o de um ente, mas o de uma operação imanente à substância enquanto disposição para o composto. Trata-se de uma disposição originária que se identifica plenamente com o dinamismo de substanciação da substância, entendida como a vida no processo da sua efectividade, já que só o vivo é um composto dotado de unidade e, portanto, de substancialidade: "Mas assim restrinjo a substância corpórea ou composta exclusivamente aos vivos ou às únicas máquinas da natureza"28.

O vinculum substancial e unional é a operação genesíaca do vivo e o seu modo de efectividade enquanto sistema autónomo cuja especialização e diferenciação interna reforça a coesão do todo: um "artifício infinitamente maravilhoso", que Leibniz baptiza com um neologismo inventado em simultâneo pelo Filósofo e pelo médico G. E. Stahl - organismo. Este "outra coisa não é senão um mecanismo mais divino cuja subtileza vai ao infinito"29, ou, nos termos do $\S 64$ da Monadologia, "as máquinas da natureza, isto é, os corpos vivos são máquinas também nas suas partes mais ínfimas até ao infinito”. A mais ínfima porção de matéria orgânica envolve a vida na sua dimensão comunitária.

O organismo evidencia a plasticidade e a finalidade da própria natureza, no quadro de uma filosofia da vida cujo traço mais notável é a interdependência entre o ser vivo singular e o mundo da vida. A vida é para o vivo, que se constitui no seio desta mesma vida. O carácter próprio do universo monadológico, definido pela vida, é o de uma comunidade de membros que se acomodam e entre-exprimem mutuamente: "Ora, esta ligação ou este acomodamento de todas as coisas criadas com cada uma e de cada uma com todas as outras leva a que cada substância simples tenha relações que exprimem todas outras e que, por conseguinte, ela seja um espelho vivo perpétuo do universo"30.

2. A mediação corporal e linguística. A mónada é o requisito fundamental da constituição do vivo, o alfabeto da vida, o elemento genesíaco das coisas. Há graus, desde o nível mais embrionário e incipiente de organização - a simples mónada nua - até ao espírito mais elevado.

O espírito consuma a natureza, esta é o meio no qual se realiza o espírito, o teatro da sua efectividade. Longe de ser um obstáculo à realização do espírito, o corpo é uma condição da sua completude, já que "não

\footnotetext{
27 “(...) a continuidade real só pode nascer do vínculo” (Carta a Des Bosses, GP II, p. 517).

${ }^{28}$ Carta a Des Bosses, 29. 05. 1716, GP II, p. 520.

${ }^{29}$ Consequencias Metafísicas do princípio de razão, C, p. 16.

${ }^{30}$ Monadologia, § 56.
} 
há percepções sem órgãos”31. Um espírito desenraizado do mundo fenomenal seria uma aberração, uma entidade inteiramente amorfa, agindo caoticamente e uma espécie de "desertor da ordem universal"32. O corpo é mediador universal de ordem. Assim, um mundo de puros espíritos seria um mundo atomístico, constituído por entidades discretas e ordenadas, incapazes de participar em qualquer tipo de ordem. Daí a tese de que o melhor dos mundos é um mundo de almas e corpos mutuamente ajustados: "Por conseguinte, o melhor sistema das coisas não conterá deuses; será sempre um sistema de corpos, isto é, de coisas dispostas segundo os lugares e os tempos, e de almas que representam e apercebem os corpos"33.

O espírito não pode prescindir da ligação ao corpo porque ele é um requisito da sua interioridade e da sua capacidade expressiva ${ }^{34}$. A própria relação de si consigo, ou a consciência, é mediada pelo corpo ${ }^{35}$, sendo por isso uma experiência insuperavelmente confusa ${ }^{36}$.

A filosofia leibniziana da corporeidade transporta consigo uma concepção da linguagem cujo ponto de perspectiva é a inviabilidade de um pensamento puro, exercendo-se aquém da linguagem ${ }^{37}$. A linguagem é um análogo do corpo, desempenhando relativamente ao pensamento a mesma função que o corpo relativamente ao espírito: condição do seu exercício e fonte da sua determinação. Essa analogia, da qual decorre que a linguagem não é mera verbalização de um pensamento constituído independentemente dela, está bem expresso nos Novos Ensaios: "E estou persuadido de que a alma e os espíritos não estão nunca sem órgãos e também nunca sem sensações, como também não poderia raciocinar sem caracteres.”38

${ }^{31}$ Carta a Hartsoeker, 7. 12. 1711, GP III, p. 529.

32 Considérations sur les principes de vie, GP VI, p. 546.

${ }^{33}$ Essais de Théodicée, art.200.

34 “(...) é pelo corpo e pelas coisas corporais que a alma é o que é, pensa o que pensa e faz tudo o que faz" (Carta à rainha Carlota Sofia, GP VI, p. 511).

35 "Nós não conhecemos a alma por si própria, mas unicamente pelo corpo e, consequentemente, pelos sentidos e pelas coisas sensíveis.” (Op. cit., p. 510).

36 "Para entender o que é o eu, não basta que eu me sinta uma substância que pensa, seria preciso conceber distintamente o que me distingue de todos os outros espíritos possíveis, mas disso eu tenho apenas uma experiência confusa.” (Carta a Arnauld, Junho de 1686, GP II, pp. 52-53).

37 "Embora o homem raciocine sobre coisas abstractas e que ultrapassam a imaginação, ele não deixa de ter na imaginação signos que lhes correspondem, como são as letras e os caracteres. Não há nunca entendimento tão puro que não seja acompanhado por alguma imaginação.” (Extrait du Dictionaire de M. Bayle article Rorarius avec mes remarques, GP IV, p. 541).

38 Leibniz, Nouveaux Essais, II, XXXI, 73, GP V, p. 191. 
A linguagem é a casa do pensamento, o seu habitat próprio. Leibniz demarca-se, pois, da tendência cartesiana, muito expressamente formulada por Cordemoy, de que os espíritos comunicam imediatamente os seus pensamentos uns aos outros, sendo essa a mais genuína comunicação, a que a linguagem cria obstáculo, em virtude da sua natureza sensível ${ }^{39}$. Ora, leibnizianamente, é o carácter sensível da linguagem que lhe confere o seu poder expressivo e a aptidão para representar as coisas exteriores. De facto, não há pensamento puro e abstracto, desligado da realidade sensível: "Os pensamentos respondem sempre a alguma sensação"40.

A linguagem é intrinsecamente portadora de significação ${ }^{41}$, a riqueza de uma língua reside precisamente na sua capacidade expressiva ${ }^{42}$, que faz dela o órgão do pensar. Com efeito, o pensamento é imanente ao espírito, mas ele efectiva-se através da apropriação das potencialidades inscritas na língua de nosso uso. Assim, a linguagem faz a ponte entre a subjectividade interior e a inteligibilidade comum.

3. A comunidade moral dos espíritos. A passagem da natureza ao espírito significa um aumento de comunicação. Efectivamente, a superioridade do espírito revela-se pela sua capacidade de exprimir Deus e entrar em sociedade com ele ${ }^{43}$, tornando-se membro da cidade de Deus, sem quebrar o vínculo com a natureza material: a cidade de Deus é "um mun-

39 "Porque, finalmente, o espírito deve mais facilmente perceber um pensamento do que o signo desse pensamento, já que esse signo é uma coisa corporal. Assim, julgo que é mais natural aos espíritos manifestarem-se, isto é, comunicarem-se os seus pensamentos por si mesmos e sem quaisquer signos, do que falarem uns com os outros, isto é, comunicarem-se os seus pensamentos mediante signos, que são de uma natureza muito diferente da dos pensamentos.” (Cordemoy, Gérauld de, Discours physiqye de la parole, Paris, 1668, p. 61).

${ }^{40}$ Nouveaux Essais, II, I, 23, GP V, p. 108.

41 “O valor originário do signo (...) é a sua significação” (Fundamenta calculi ratiocinatoris, GP VII, p. 206).

42 “A riqueza é, para a linguagem, a primeira e a mais necessária das suas qualidades. Consiste em que ela não apresenta nenhuma falha, mas, pelo contrário, uma superabundância de palavras expressivas e facilmente acessíveis, úteis para a expressão de todo o acontecimento, de maneira que tudo possa ser exposto com força e verdade, pintado com cores vivas." (Considérations inattendues sur l'usage et l'amélioration de la langue allemande, in L'harmonie des langues, Paris, Seuil, 2000, p. 81)

43 “E como o próprio Deus é o maior e o mais sábio dos espíritos, é fácil julgar que os seres com os quais ele pode, por assim dizer, entrar em conversação e mesmo em sociedade, comunicando-lhes os seus sentimentos e as suas vontades de uma maneira particular, e de tal modo que eles possam conhecer e amar o seu benfeitor, o devem tocar infinitamente mais do que o resto das coisas, que apenas podem passar por instrumentos dos espíritos” (Discurso de Metafisica, art. 35). 
do moral no mundo natural"44. Deus comunica-se aos espíritos, cuja receptividade contribui para a glória divina: “Com efeito, posto que Deus é espírito e o mais perfeito de todos, vejo bem que ele será o mais feliz e o mais satisfeito. E também vejo bem que ele se comunicará com os outros espíritos [itálico meu] e que receberá muito mais prazer, se me é permitido falar assim, do seu Reino sobre os espíritos do que do seu poder sobre os corpos. (...) E os espíritos que pensam em Deus, que raciocinam sobre ele e de algum modo como ele na medida em que conhecem a verdade, devem sem dúvida tocá-lo incomparavelmente mais do que todas as criaturas brutas" ${ }^{45}$. Ora, qual o modo dessa comunicação. Como é que Deus se comunica com os espíritos? Como é que estes participam na realização da obra divina? Como é que exprimem e imitam a Deus? A resposta leibniziana mais elaborada a este emaranhado de questões encontra-se na mesma passagem do Diálogo que acaba de ser citado: "Pois, considerado sem os espíritos, o universo é uma única vez: mas cada espírito é uma nova maneira de exprimir ou de representar o universo segundo Deus o olha por assim dizer de um certo lado" (ibidem). Pela sua expressão, os espíritos multiplicam indefinidamente o mundo actual, recriando-o à sua maneira, "através de escantilhões arquitectónicos, cada espírito sendo como que uma pequena divindade no seu departamento" 46 .

O que julgo interessante é que Deus se comunique e entre em sociedade com os espíritos seguindo as vias naturais - o bom uso da razão e o sentimento ajustado para com o mundo. A religião natural é a única base da catolicidade no sentido genuíno de uma religião verdadeiramente universal: “Assim, a razão é o princípio de uma religião universal e perfeita, que se pode justamente chamar a lei da natureza. (...) a Lei da Natureza é a religião Católica" ${ }^{\prime 4}$.

A revelação destina-se a restabelecer a religião natural, não a anulá-la. Deus revela-se por vias sobrenaturais, mas também na imanência do exercício pensante: "A razão é a voz natural de Deus" 48 .

O pensamento racional distingue-se da simples percepção natural na medida em que não está limitado aos fenómenos do mundo actual, exercendo-se sobre o modo e o princípio de constituição desse mesmo mundo. E, mais, sobre a própria natureza do ser divino, que contém em si todas as perfeições no grau supremo.

${ }^{44}$ Monadologia, art. 85.

45 Dialogue entre Theophile et Polidore, A VI, IV, C, p. 2237.

46 Monadologia, art. 83.

47 Parallèle entre la raison originale ou la loy de la nature, le paganisme ou la corruption de la loy de la nature et le christianisme ou la loy de la nature retablie, Grua, I, p. 49.

48 Carta a Morell, Setembro de 1698, Grua, I, p. 138. 
Da justa consideração do ser divino, no qual está implicada a perfeição da sua obra - já que a sua vontade está intrinsecamente ordenada ao óptimo - decorre um afecto especial: a alegria ou o estado duradouro de prazer. A alegria é o fundamento da religião e da piedade ${ }^{49}$, na medida em que dispõe o espírito a perceber o espírito na sua significação moral. De facto, "as coisas estão feitas de uma maneira que ultrapassa os nossos desejos" 50 , pelo que o descontentamento, a tristeza, o mau humor e o ódio provêm de uma visão desfocada: "Não há indignação justa na República universal” ${ }^{\prime}$.

O Deus de Leibniz é um excelente geómetra, cujo entendimento se exerce nos mais finos jogos combinatórios, mas não é essa a sua verdadeira fisionomia. Ele é o Deus do amor, que, pelo exercício da vontade, faz existir toda a perfeição que o mundo das criaturas pode comportar. Enquanto sentimento que se dirige preferencialmente aos espíritos, o amor é deleitação com a felicidade do outro: amar é sentir prazer no prazer do outro, um modo de intensificação do afecto.

Experiência de alteridade, o amor é o vínculo da sociedade entre os homens e destes com deus, sendo o mediador da união das vontades num mesmo querer, segundo uma definição clássica do amor, retomada no Discurso de Metafisica ${ }^{52}$. Na sua dimensão mais profunda, o amor é desejo do desejo do outro, acrescentando à simpatia natural uma nova dimensão que faz dela a base de uma comunidade moral, expressa numa ordem de com-sentimento e de com-paixão.

Numa Europa atravessada por divisões e conflitos entre as diversas confissões cristãs, Leibniz assume o cristianismo como uma religião interior, que aprofunda a sociedade íntima com Deus, inerente ao ser humano enquanto tal: "nós temos uma sociedade íntima com Deus"53. Na sua essência, a Igreja é uma comunidade moral cujo selo é a caridade e a benevolência para com o outro, nomeadamente aquele que, por nascimento e educação, vive numa confissão distinta da romana. O espírito sectá-

49 “(...) o bom humor, isto é, o contentamento ou a alegria é o mais seguro fundamento da religião e da piedade (...) e não há praticamente mais nada senão o mau humor que possa fazer cair no ateísmo" (Carta a Coste, 1706, GP III, p. 412).

50 Princípios da Natureza e da Graça, art. 16.

51 Confessio Philosophi, A VI, III, p. 140.

52 “O conhecimento geral da grande verdade, segundo a qual Deus age sempre da maneira mais perfeita e mais desejável possível, é, na minha opinião, o fundamento do amor que devemos a Deus sobre todas as coisas, pois quem ama procura a sua satisfação na felicidade ou perfeição do objecto amado e das suas acções. Idem velle et idem nolle vera amitia est (A verdadeira amizade consiste em querer o mesmo e não querer o mesmo)." (Discurso de Metafisica, art. 4).

53 Tentamina quaedam ad novum codicem legum condendum, A VI, IV, C, p. 2867. 
rio, o hábito da excomunhão, o afrontamento e exclusão do outro são a marca da "política humana" 54 , não do verdadeiro zelo pelas coisas divinas. O Papa e restantes dignitários eclesiásticos não têm o poder para excluir da verdadeira Igreja católica aquele que age em consciência, movido pelo amor. A união entre os cristãos está votada ao fracasso enquanto for entendida mais como uma tarefa política, dependente de condicionalismos vários, do que um empreendimento moral e a promoção de uma cultura de paz.

4. Diálogo de culturas. A adesão de Leibniz à corrente sinófila protagonizada pelos Jesuítas é um episódio relevante na sua procura de uma nova humanidade, superando barreiras que a história foi gradualmente sedimentando, como seja aquela que opõe a Europa cristã às culturas não-europeias.

O encontro da Europa com a China é exemplar porque revela uma afinidade muito profunda entre sistemas culturais com uma identidade bem marcada. A distância e a estranheza entre chineses e europeus é mutuamente empobrecedora: o encontro entre estes dois mundos representa uma oportunidade de reencontro de cada um deles consigo mesmo, reforçando a sua identidade. Mais do que em qualquer outro domínio, a diferença é, no plano histórico-antropológico, condição de relação genuína e fonte de uma verdadeira unidade, a não confundir com a homogeneidade descaracterizadora.

Nos termos do prefácio à Novissima Sinica (1697), nenhum dos "partidos" é superior ao outro, cada um deles desenvolveu mais certos aspectos e aprofundou domínios específicos, tendo algo de novo a comunicar: "Continuando, o Império chinês, cuja superfície não é inferior à da Europa cultivada e, inclusive, a ultrapassa em população, comporta muitas coisas pelas quais rivaliza connosco e, com armas aproximadamente iguais, é ora vencedor ora vencido. Mas, para dizer o essencial, pois dar conta de todos os pormenores seria um trabalho sem dúvida útil, mas longo e inoportuno, no que respeita às artes úteis ao uso da vida e à experiência das coisas naturais, somos porventura iguais na balança e cada partido tem interesse em comunicar com o outro, para seu benefício, em alguma matéria"55. Comunicar significa, a este nível, pôr em comum algo

54 "V. A. deve estar reconhecida à boa vontade da Sra. Brinon, que lhe abre o paraíso, se ouvirmos o seu conselho. Ela supõe que Roma é a única via de acesso ao paraíso. Mas ligar as graças divinas a este tipo de condições que a política humana inventou é ter ideias muito estranhas a respeito de Deus" (Carta à Princesa Sofia, Julho de 1697, A, I, XVI, p. 37).

55 Prefácio à Novissima Sinica, in Leibniz, Discours sur la théologie naturelle des chinois plus quelques écrits sur la question religieuse de Chine, par C. Frémont, Paris, 1987, p. 58. Doravante, esta obra será referida como Frémont. 
de particular, fazer um intercâmbio que seja enriquecedor para os dois lados: "É justo que a utilidade seja recíproca já que nos tornaríamos inferiores a eles, se eles aprendessem connosco sem dar nada em troca”56.

O léxico leibniziano é especialmente rico na abordagem do intercâmbio euro-chinês. Por um lado, há proximidade, parentesco ${ }^{57}$, que Leibniz exprime pelos termos "correspondência" 58 , paralelismo" 59 , "analogia”60, "expressão" (ibid.); por outro, há complementaridades, desenvolvimento desigual, apelando à "troca" 61 , "transporte"62, "transplantação dos conhecimentos e inclusive das coisas" ${ }^{3}$ e, talvez o mais surpreendente, "infusão de conhecimentos": "Finalmente, Vossa Reverência far-me-á um grande favor se me ensinar alguns pormenores tanto a respeito daquilo que foi trazido da China como daquilo que para lá foi e vier a ser transportado. (...) porque nós poderemos dar-lhes como que de chofre e por uma espécie de infusão (par une manière d'infusion) os nossos conhecimentos e, pelo nosso lado, poderemos receber deles também de chofre um mundo de novos saberes (un monde de nouvelles notices), que sem isso de modo nenhum teríamos obtido em não sei quantos séculos”64. Infusão é uma palavra carregada de sentido. Na tradição cristã, designa a transmissão súbita de conhecimentos pelo Espírito Santo aos Apóstolos no intuito de suprir a sua falta de preparação no que respeita, por exemplo, às línguas dos Povos a evangelizar. O encontro entre europeus e chineses é um momento extraordinariamente exaltante, uma oportunidade única de enriquecimento e de correcção de certos desvios, como seja a tendência da metafísica ocidental para a abstracção ou a tendência da nossa teologia para o sectarismo dogmático.

Grande entusiasta da missão dos Jesuítas, Leibniz considera que ela só fará pleno sentido se a conversão dos chineses ao cristianismo for acompanhada pela conversão a si mesmos, às raízes da sua tradição, e se for contrabalançada pelo movimento inverso: o envio de missionários

56 Carta ao P. ${ }^{e}$ Bouvet, 2.12. 1697.

${ }^{57}$ No Discurso sobre a teologia natural dos chineses, é notável o esforço para mostrar que o Li dos chineses mais não é do que outro modo de dizer Deus ou o Ser perfeito ou a Natureza naturante (Discurso sobre a teologia natural dos chineses, Lisboa, Colibri, 1991, pp. 42-43).

58 Op. cit., p. 86.

59 Ibidem.

60 Carta ao P. ${ }^{e}$ Verjus, 18. 08. 1705.

61 Carta ao P. $^{e}$ Bouvet, 2.12. 1697.

62 Carta ao P. ${ }^{e}$ Bouvet, 2. 12. 1697.

63 Carta ao P. ${ }^{e}$ Bouvet, 13. 12. 1707.

${ }^{64}$ Carta ao P. $^{e}$ Bouvet, 2. 12. 1697, Frémont, pp. 175-176. 
chineses à Europa, para difundirem os princípios da religião natural e de uma sábia governação.

Conclusão. A comunicação é uma dimensão intrínseca do agir entendido como dinamismo expressivo. Ser é originariamente ser-com, da mesma maneira que o pensar envolve sempre o outro e mesmo o Infinito no seio do qual nos movemos. Do ponto de vista leibniziano, não há inteligibilidade fechada, o confronto de argumentos é o modo específico do exercício filosófico. Nas palavras do autor, "o lugar do outro é o verdadeiro ponto de perspectiva em política e moral”65, mas também no domínio da cognição. Efectivamente, o reconhecimento e passagem pelo lugar do outro é o traço característico pelo qual se faz a marcação do filósofo relativamente ao pensamento vulgar, sempre de algum modo afectado pelo espírito de seita ou de partido: "Ligamo-nos às pessoas, às leituras e às considerações favoráveis, a um certo partido, não prestamos a mínima atenção àquilo que vem do partido contrário e por essas habilidades e mil outras que empregamos o mais das vezes sem intenção e sem reflexão, acabamos por nos enganar ou perverter segundo o que encontrámos”66. O modus operandi de Leibniz apela a uma concepção da razão como espaço de essencial diálogo, em que o outro, longe de ser objecto de um olhar exterior e distanciado, é ele próprio um ponto de perspectiva que dá razão do olhar que nele se vê.

\section{Bibliografia}

Cardoso, Adelino, “A comunidade monadológica”, Análise 16 (1992) pp. 91-109 .

—_Leibniz segundo a expressão, Lisboa, Ed. Colibri, 1992.

_ O trabalho da mediação no pensamento leibniziano, Lisboa, Ed. Colibri, 2005.

Cariou, Marie, L'atomisme. Gassendi, Leibniz, Bergson et Lucrèce, Paris, Aubier, 1978.

Dascal, Marcelo, La semiologie de Leibniz, Paris, Aubier, 1978.

Frémont, Christiane, Singularités, Individus et Relations dans le Système de Leibniz, Paris, Vrin, 2003.

Deleuze, Gilles, Le pli. Leibniz et le baroque, Paris, Minuit, 1988.

Ferro, Nuno, A confusão das coisas e o ponto de vista leibniziano, Lisboa, IN-CM, 2001.

Gaudemar, Martine de, Leibniz. De la puissance au sujet, Paris, Vrin, 1994.

${ }^{65}$ La place d'autrui, A I, IV, p. 903.

${ }^{66}$ Novos Ensaios, II, XXI, 24, GP V, p. 155. 
Gil, Fernando, Mimesis e Negação, Lisboa, IN-CM, 1984.

Knecht, Herbert, La logique chez Leibniz. Essai sur le rationalisme baroque, Lausanne, L'Age d'Homme, 1981.

Leibniz, G. W., Discours sur la théologie naturelle des chinois plus quelques écrits sur la question religieuse de Chine, par C. Frémont, Paris, L’Herne, 1987.

_ Discurso sobre a teologia natural dos chineses, tradução e apresentação de A. Cardoso Lisboa, Ed. Colibri, 1991.

— L'harmonie des langues, apresentação e tradução de Marc Crépon, ed. Bilingue alemão-francês, Paris, Seuil, 2000.

Mendonça, Marta de, A doutrina das modalidades na filosofia de G. W. Leibniz, Lisboa, IN-CM, 2005.

Mugnai, Massimo, Leibniz Theory of Relations, Stuttgart, F. Steiner, 1992.

Pombo, Olga, Leibniz and the problem of a universal language, Münster, Nodus Publikationen Münster, 1987.

Racionero, Quintín e Roldán, Concha, G. W. Leibniz. Analogía y expresión, Madrid, Ed. Complutense, 1994.

Rutherford, Donald, Leibniz and the rational order of nature, Cambridge, CUP, 1995.

Serres, Michel, Le système de Leibniz et ses modèles mathématiques, Paris, PUF, 1968.

_ Hermès ou la communication, Paris, Minuit, 1668.

Yakira, Elhanan, Contrainte, nécessité, choix. La métaphysique de la liberté chez Spinosa et chez Leibniz, Zurich, Ed. Du Grand Midi, 1989.

\section{METAFÍSICA LEIBNIZIANA DA COMUNICAÇÃO O PARADIGMA MONADOLÓGICO}

A comunicação é uma noção axial que articula o sistema de Leibniz e elucida a lógica imanente ao evolver do seu pensamento, designadamente no plano da metafísica. De facto, na sua fase inicial, a metafísica leibniziana revela a dificuldade em articular o primado do indivíduo com a exigência de vínculo comunitário entre os seres. $\mathrm{O}$ princípio de compossibilidade enquanto requisito de autoconstituição do ente actual, a teoria da noção completa de um indivíduo e a teoria da expressão respondem ao intento de pensar o indivíduo como perfil do universal. A metafísica monadológica consuma o esforço de estabelecer a copertença originária entre a mónada singular e o universo de que faz parte. Por conseguinte, o autor demarca-se da interpretação da mónada como uma entidade solipsista, desligada do mundo e do outro, em especial na versão de A. Renault.

O lugar do outro é o verdadeiro ponto de perspectiva no domínio prático, tal como no domínio da cognição. Efectivamente, o reconhecimento do outro é o traço característico pelo qual, segundo Leibniz, se faz a marcação do filósofo relativamente ao pensamento vulgar, sempre de algum modo afectado pelo espírito de seita ou de partido. 


\section{LA METAPHYSIQUE LEIBNIZIENNE DE LA COMMUNICATION LE PARADIGME MONADOLOGIQUE}

La communication est une notion axiale qui fait l'articulation du système de Leibniz et élucide la logique immanente à l'évolution de sa pensée, nommément au niveau de la métaphysique. En effet, dans sa phase initiale, la métaphysique leibnizienne témoigne la difficulté de lier ensemble la primauté de l'individu et l'exigence du lien communautaire entre les êtres. Le principe de compossibilité comme réquisit d'autoconstitution de l'étant actuel, la théorie de la notion complète d'un individu et la théorie de l'expression répondent au dessein de penser l'individu comme profil de l'universel. La métaphysique monadologique culmine l'effort d'établir la coappartenance originaire entre la monade singulière et l'univers dont elle fait partie. Donc, l'auteur s'éloigne de l'interprétation de la monade comme une entité solipsiste, détachée du monde et d'autrui, notamment dans la version d'Alain Renaut.

La place d'autrui est le vrai point de perspective dans le domaine pratique et aussi dans le domaine de la cognition. Car la reconnaissance de l'autre est le trait caractéristique par lequel, selon Leibniz, se définit le philosophe en face de la pensée vulgaire, toujours en quelque façon affectée de l'esprit de secte ou de parti. 